\title{
Improvement of $\mathrm{Mn}_{1.56}\left(\mathrm{Co}_{1-x} \mathrm{Al}_{\mathrm{x}}\right)_{0.96} \mathrm{Ni}_{0.48} \mathrm{O}_{4}(0.1 \leq x \leq 0.4)$ Film Preparation and Assessment of Its Structure and Properties
}

\author{
QIAN WANG, ${ }^{1,2}$ JUN ZHANG, ${ }^{1}$ and WENWEN KONG ${ }^{1,3}$ \\ 1.-CAS Key Laboratory of Functional Materials and Devices for Special Environments, Xinjiang \\ Key Laboratory of Electronic Information Materials and Devices, Xinjiang Technical Institute of \\ Physics and Chemistry, CAS, Urumqi 830011, China. 2.-School of Physics Science and \\ Technology, Xinjiang University, Urumqi, China. 3.—e-mail: kongww@ms.xjb.ac.cn
}

\begin{abstract}
A series of $\mathrm{Mn}_{1.56}\left(\mathrm{Co}_{1-\mathrm{x}} \mathrm{Al}_{\mathrm{x}}\right)_{0.96} \mathrm{Ni}_{0.48} \mathrm{O}_{4}(x=0.1,0.2,0.3$, and 0.4$)$ films were prepared by the chemical solution deposition method and then post-heated at $150^{\circ} \mathrm{C}$ for $300 \mathrm{~h}$. Scanning electron microscopy and x-ray diffraction revealed remarkable improvements in relative density and crystallinity in post-heated $\mathrm{Mn}_{1.56}\left(\mathrm{Co}_{1-\mathrm{x}} \mathrm{Al}_{\mathrm{x}}\right)_{0.96} \mathrm{Ni}_{0.48} \mathrm{O}_{4}(x=0.1,0.2,0.3$, and 0.4$)$ films. From x-ray photoelectron and Raman spectroscopy, it was found that the $\mathrm{Mn}^{3+} / \mathrm{Mn}^{4+}$ ratio decreases after post-heating, which leads to a decrease in Raman mode intensity. Furthermore, spectroscopic ellipsometry results show that both the refractive indexes and extinction coefficients of post-heated films are higher than those of annealed films in the visible range. However, the band gaps of all the films decreased significantly after the heating process. These investigations suggest that the post-heating treatment may be preferable for fabricating $\mathrm{Mn}_{1.56} \mathrm{Co}_{0.96} \mathrm{Ni}_{0.48} \mathrm{O}_{4}$ thin films for optical detection.
\end{abstract}

Key words: Structure, optical properties, post-heated, films

\section{INTRODUCTION}

Manganese-based oxides with spinel structures of the general formula $\mathrm{AB}_{2} \mathrm{O}_{4}$ have been extensively utilized in thermistor devices and, especially, for bolometer infrared detectors, and for commercial and space travel applications. ${ }^{1,2}$ The compound $\mathrm{Mn}_{1.56} \mathrm{Co}_{0.96} \mathrm{Ni}_{0.48} \mathrm{O}_{4}$ has a unique composition that has a low resistivity and a high sensitivity to negative temperatures. This makes it suitable for providing optimum performance in the bolometer infrared detectors used in satellites. ${ }^{2}$ The physical properties of $\mathrm{Mn}-\mathrm{Co}-\mathrm{Ni}$-O-based materials depend on variations in the distribution of cations in the spinel structure, ${ }^{2,3}$ which is influenced by the composition and processing of the material. ${ }^{4-6}$ The effect of adding other metal cations to the structures of Mn-Co-Ni-O-based materials on their physical

(Received August 14, 2018; accepted January 16, 2019; published online January 25, 2019) properties has recently been a subject of systematic study. ${ }^{7,8}$ It has been reported that $\mathrm{Al}^{3+}$ entering $\mathrm{Mn}$ Co-Ni-O grains significantly facilitates optical absorption in the $0.63-2 \mu \mathrm{m}$ wavelength range, which is significant in the design and application of infrared detectors. ${ }^{9}$

To date, $\mathrm{Mn}_{1.56} \mathrm{Co}_{0.96} \mathrm{Ni}_{0.48} \mathrm{O}_{4}(\mathrm{MCN})$ films have been fabricated by laser molecular beam epitaxy, the pulsed laser deposition method, RF magnetron sputtering, chemical solution deposition (CSD), and so on. Among these, the CSD method has attracted considerable interest in recent years as it is a simple, low-cost technology for oxide-based spintronics. The Mn-Co-Ni-O-based films fabricated by the CSD method combine the advantages of both Mn-Co-Ni-O-based ceramic bulk and thin films. Some efforts have been made to study sintering and other processes used in the CSD method that result in various oxygen stoichiometries and metal cation distributions in Mn-Co-Ni-O-based films. ${ }^{9,10}$ The suitable crystalline temperature of Mn-Co-NiO-based films is $1100-1400^{\circ} \mathrm{C}^{11,12}$ However, in 


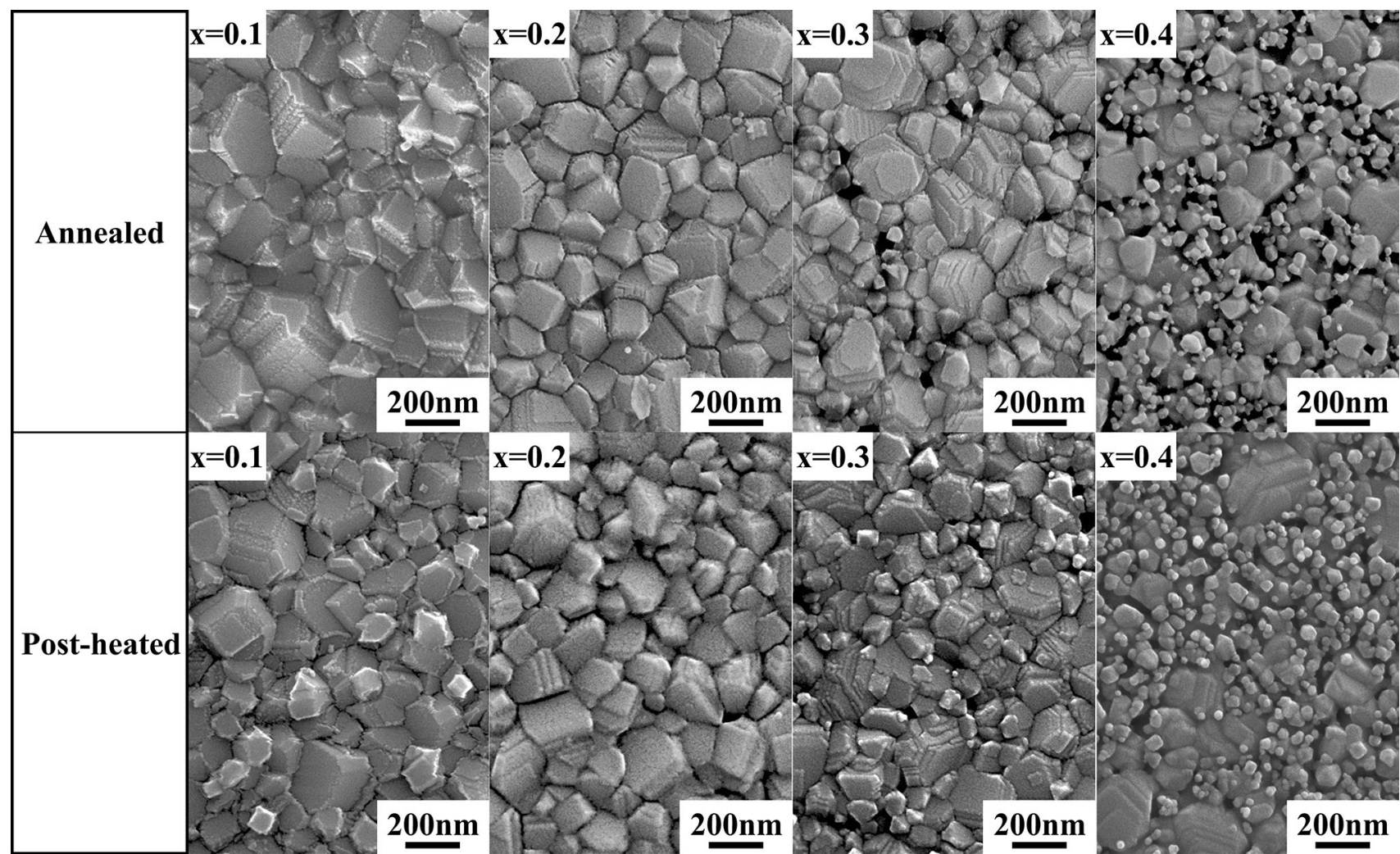

Fig. 1. SEM images of the $\mathrm{Mn}_{1.56}\left(\mathrm{Co}_{1-x} A \mathrm{I}_{\mathrm{x}}\right)_{0.96} \mathrm{Ni}_{0.48} \mathrm{O}_{4}(x=0.1,0.2,0.3$ and 0.4$)$ films.

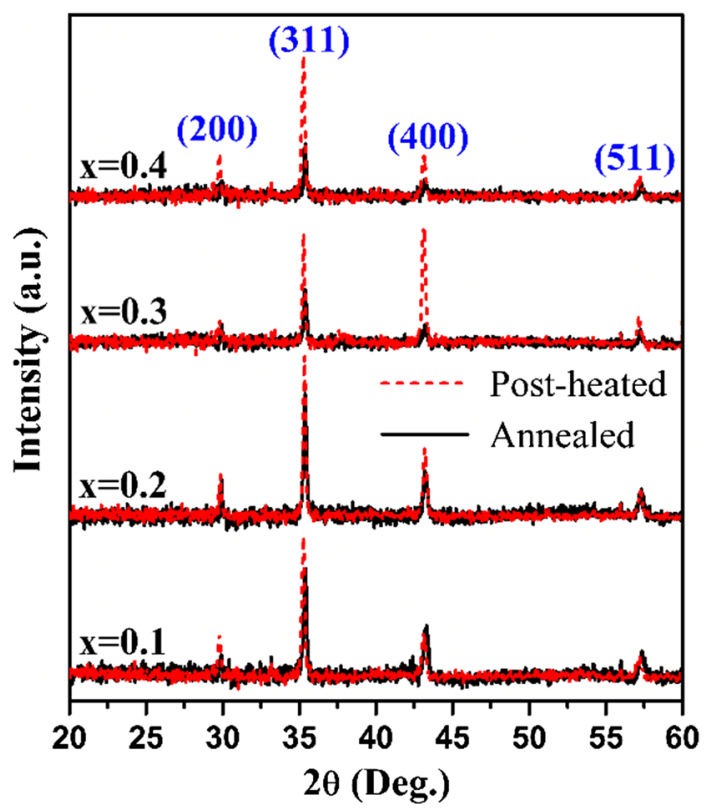

Fig. 2. XRD patterns of the $\mathrm{Mn}_{1.56}\left(\mathrm{Co}_{1-\mathrm{x}} \mathrm{Al}_{\mathrm{x}}\right)_{0.96} \mathrm{Ni}_{0.48} \mathrm{O}_{4} \quad(x=0.1$, $0.2,0.3$ and 0.4 ) films.

order to make the films match well to the substrate, films prepared by the CSD method are annealed at a temperature of $750^{\circ} \mathrm{C}$. The application of films prepared by the low-cost CSD method is limited, because their quality and stability are low. ${ }^{13,14}$
Advances in film preparation technology are necessary for the CSD method. Considering that temperature is the main factor affecting stability, a temperature compensation process was incorporated in our experiments.

In this paper, we prepared $\mathrm{Mn}_{1.56}\left(\mathrm{Co}_{1-\mathrm{x}} \mathrm{Al}_{\mathrm{x}}\right)_{0.96} \mathrm{Ni}_{0.48} \mathrm{O}_{4}(x=0.1,0.2,0.3$, and $0.4)$ films on Si substrates by the CSD method. Then, all films were post-heated at $150^{\circ} \mathrm{C}$ for $300 \mathrm{~h}$ in an air-drying oven. Investigation of the microstructure and optical properties of the films after the post-heating process will provide useful information for optimization of the CSD method and preparation of high-quality negative temperature coefficient thin films.

\section{EXPERIMENTAL}

A series of films with compositions of $\mathrm{Mn}_{1.56}\left(\mathrm{Co}_{1-\mathrm{x}} \mathrm{Al}_{\mathrm{x}}\right)_{0.96} \mathrm{Ni}_{0.48} \mathrm{O}_{4}(x=0.1,0.2,0.3$ and $0.4)$ were fabricated by a CSD method. Powders of $\mathrm{Mn}\left(\mathrm{CH}_{3} \mathrm{COO}\right)_{2} \cdot 4 \mathrm{H}_{2} \mathrm{O}, \quad \mathrm{Co}\left(\mathrm{CH}_{3} \mathrm{COO}\right)_{2} \cdot 4 \mathrm{H}_{2} \mathrm{O}$ and $\mathrm{Ni}\left(\mathrm{CH}_{3} \mathrm{COO}\right)_{2} \cdot 4 \mathrm{H}_{2} \mathrm{O}$ were mixed and dissolved in glacial acetic acid at $60^{\circ} \mathrm{C}$ for $1.5 \mathrm{~h}$. Then, $\mathrm{Al}\left(\mathrm{NO}_{3}\right)_{3} \cdot 9 \mathrm{H}_{2} \mathrm{O}$ was added to the former solution after it had cooled to room temperature, and then was stirred with a magnetic stirrer for $2 \mathrm{~h}$. The precursor solution was filtrated using a $0.45 \mu \mathrm{m}$ syringe filter after it had sat for $24 \mathrm{~h}$. A precursor solution with a concentration of $0.2 \mathrm{~mol}$ was then prepared. The pellucid precursor solution was spin- 
coated on $\mathrm{Si}$ (100) substrates to form a layer of wet film. The spin coater was set at $500 \mathrm{rpm}$ for $5 \mathrm{~s}$ and $4000 \mathrm{rpm}$ for $20 \mathrm{~s}$. The wet film was put into a tube furnace and heated at $350^{\circ} \mathrm{C}$ for $5 \mathrm{~min}$ to eliminate water and acetic acid. The above spin-coating and wet-film-drying procedures were repeated ten times. Finally, all the samples were annealed at $750^{\circ} \mathrm{C}$ for $60 \mathrm{~min}$ in air. The post-heating process occurred in a drying oven at $150^{\circ} \mathrm{C}$ for $300 \mathrm{~h}$.

The crystal structures of the $\mathrm{Mn}_{1.56}\left(\mathrm{Co}_{1-\mathrm{x}} \mathrm{Al}_{\mathrm{x}}\right)_{0.96} \mathrm{Ni}_{0.48} \mathrm{O}_{4}(x=0.1,0.2,0.3$ and 0.4 ) films were identified by x-ray diffraction (XRD;
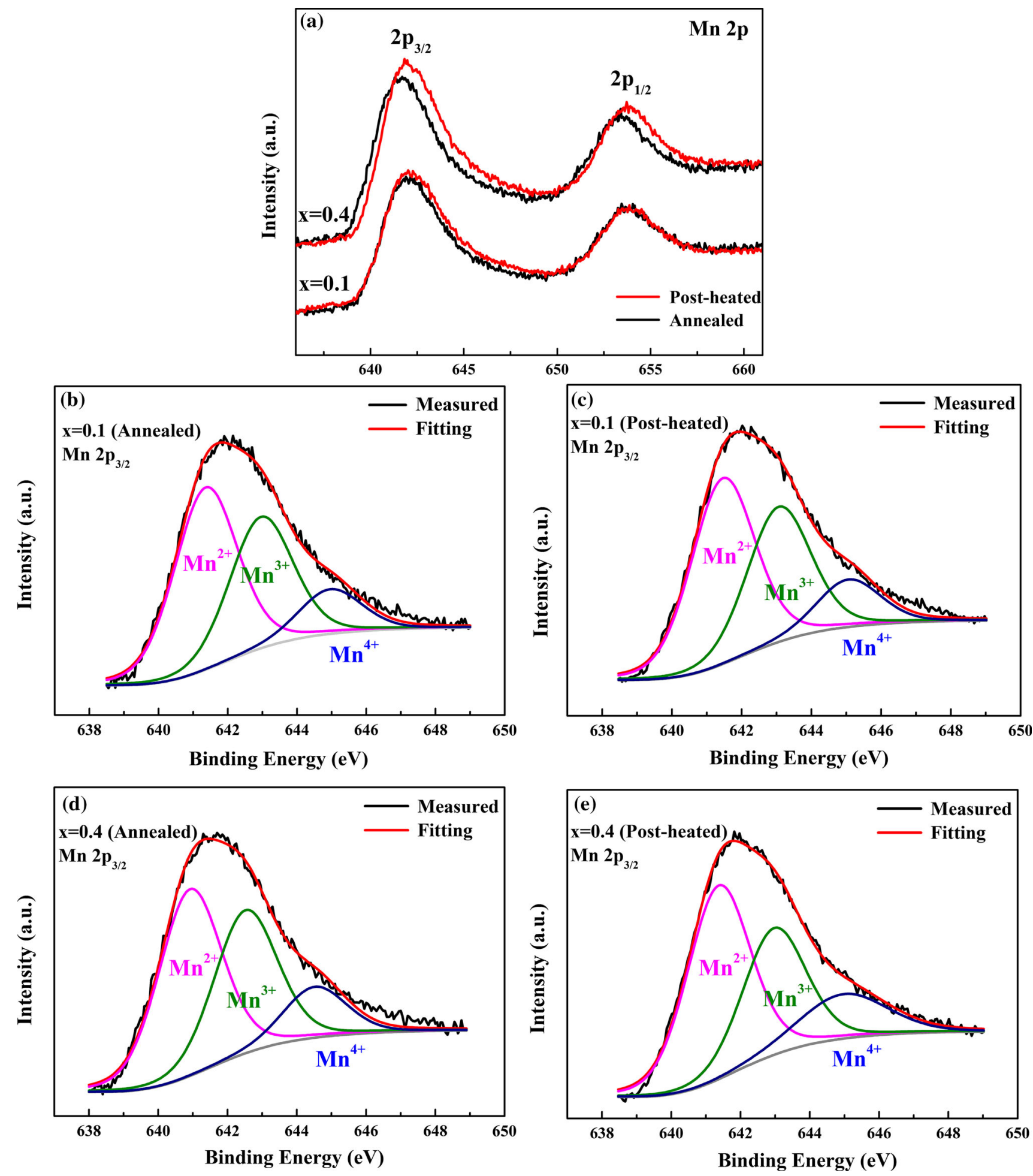

Fig. 3. XPS spectra of $\mathrm{Mn} 2 \mathrm{p}$ and their signals for the $\mathrm{Mn}_{1.56}\left(\mathrm{Co}_{1-\mathrm{x}} \mathrm{Al}_{\mathrm{x}}\right)_{0.96} \mathrm{Ni}_{0.48} \mathrm{O}_{4}$ films $(x=0.1$ and 0.4$)$. 
Table I. The ratios of $\mathrm{Mn}^{3+} / \mathrm{Mn}^{4+}$ for $\mathrm{Mn}_{1.56}\left(\mathrm{Co}_{1-\mathrm{x}} \mathrm{Al}_{\mathrm{x}}\right)_{0.96} \mathrm{Ni}_{0.48} \mathrm{O}_{4}(x=0.1$ and 0.4$)$ films

\begin{tabular}{|c|c|c|c|c|}
\hline & \multicolumn{2}{|c|}{$x=0.1$} & \multicolumn{2}{|c|}{$x=0.4$} \\
\hline & Annealed films & Post-heated films & Annealed films & Post-heated films \\
\hline $\mathrm{Mn}^{2+}(\%)$ & 50.90 & 50.43 & 49.05 & 50.66 \\
\hline $\mathrm{Mn}^{3+}(\%)$ & 36.66 & 36.67 & 37.59 & 33.16 \\
\hline $\mathrm{Mn}^{4+}(\%)$ & 12.44 & 12.90 & 13.36 & 16.18 \\
\hline $\mathrm{Mn}^{3+} / \mathrm{Mn}^{4+}$ & 2.948 & 2.844 & 2.812 & 2.049 \\
\hline
\end{tabular}

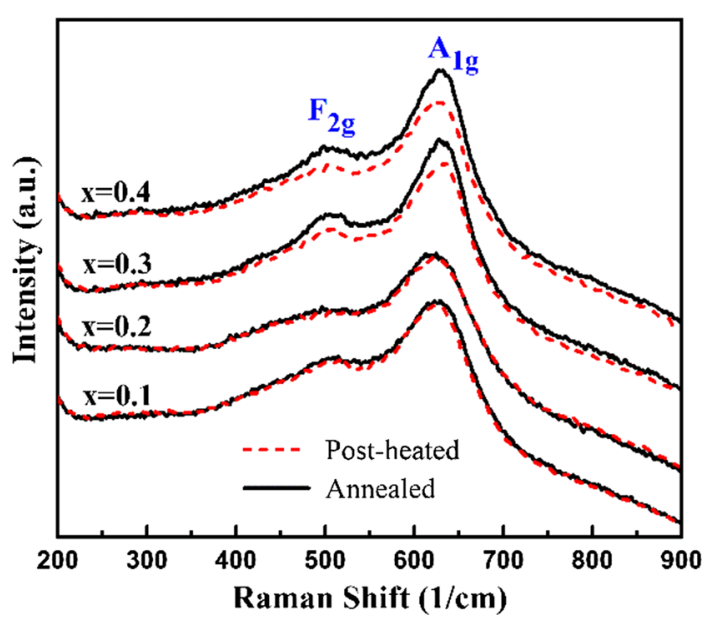

Fig. 4. Raman spectra of $\mathrm{Mn}_{1.56}\left(\mathrm{Co}_{1-x} \mathrm{Al}_{\mathrm{x}}\right)_{0.96} \mathrm{Ni}_{0.48} \mathrm{O}_{4}(x=0.1,0.2$, 0.3 and 0.4 ) films.

Bruker D8) in the range of $20^{\circ}-60^{\circ}$. The surface micrographs were represented by a scanning electron microscope (SEM; Zeiss Supra55VP). The distribution of the cations in films were characterized using an x-ray photoelectron spectroscopy (XPS, Kratos). Information on chemical bonds was measured by a micro-Raman spectrometer (NRS1000) using an $\mathrm{Ar}^{+}$laser ( $20 \mathrm{~mW}, 532 \mathrm{~nm}$ ) with the excitation source in the backscattering configuration. The optical parameters were measured by spectroscopic ellipsometry (Sentech SE850) with an incident angle of $70^{\circ}$ across the spectral range of $300-1800 \mathrm{~nm}$. The refractive index $n$ and extinction coefficient $k$ were calculated using software.

\section{RESULTS AND DISCUSSION}

Figure 1 illustrates SEM micrographs of the annealed and the post-heated $\mathrm{Mn}_{1.56}\left(\mathrm{Co}_{1-\mathrm{x}} \mathrm{Al}_{\mathrm{x}}\right)_{0.96} \mathrm{Ni}_{0.48} \mathrm{O}_{4}(x=0.1,0.2,0.3$ and 0.4) films. The average particle sizes decreased significantly as the number of $\mathrm{Al}^{3+}$ cations increased. The $\mathrm{Mn}_{1.56}\left(\mathrm{Co}_{0.9} \mathrm{Al}_{0.1}\right)_{0.96} \mathrm{Ni}_{0.48} \mathrm{O}_{4}$ and $\mathrm{Mn}_{1.56}\left(\mathrm{Co}_{0.8} \mathrm{Al}_{0.2}\right)_{0.96} \mathrm{Ni}_{0.48} \mathrm{O}_{4}$ films were quite dense. However, the other films had a porous microstructure. This demonstrates that the compactness deteriorates after the addition of $\mathrm{Al}^{3+}$ cations in the MCN films. Although the post-heating process had no influence on the sizes and shapes of the grains, all the films became much denser and more compact after post-heating.

The XRD patterns of the annealed and postheated $\mathrm{Mn}_{1.56}\left(\mathrm{Co}_{1-\mathrm{x}} \mathrm{Al}_{\mathrm{x}}\right)_{0.96} \mathrm{Ni}_{0.48} \mathrm{O}_{4}(x=0.1,0.2,0.3$ and 0.4) films deposited on $\mathrm{Si}(100)$ substrates are shown in Fig. 2. Spinel structures were observed for all films by making reference to $\mathrm{NiMn}_{2} \mathrm{O}_{4}$ with the PDF card no. 84-0542, showing four distinct peaks. This demonstrates that $\mathrm{Al}^{3+}$ cations had been diffused into the $\mathrm{Mn}-\mathrm{Co}-\mathrm{Ni}-\mathrm{O}$ lattice to form a homogeneous solid solution. The corresponding diffraction peaks of the $\mathrm{Mn}_{1.56}\left(\mathrm{Co}_{1-\mathrm{x}} \mathrm{Al}_{\mathrm{x}}\right)_{0.96} \mathrm{Ni}_{0.48} \mathrm{O}_{4}$ $(x=0.1,0.2,0.3$ and 0.4$)$ films become sharper and stronger after post-heating, which indicates a further improvement in their crystallinity. In addition, all the peaks shifted slightly towards lower $2 \theta$ angles after the heating process. Such features are related to cation redistribution and lattice expansion. ${ }^{15}$ In Mn-based spinel materials, the lattice constant, as well as physical properties, are mainly affected by changes in the variation of the manganese ion octahedral and tetrahedral distributions. ${ }^{16}$

In order to compare the variation in the valence states of manganese between the annealed and the post-heated $\mathrm{Mn}_{1.56}\left(\mathrm{Co}_{1-\mathrm{x}} \mathrm{Al}_{\mathrm{x}}\right)_{0.96} \mathrm{Ni}_{0.48} \mathrm{O}_{4} \quad(x=0.1$, $0.2,0.3$ and 0.4 ) films, the XPS spectra for the $\mathrm{Mn}_{1.56}\left(\mathrm{Co}_{1-\mathrm{x}} \mathrm{Al}_{\mathrm{x}}\right)_{0.96} \mathrm{Ni}_{0.48} \mathrm{O}_{4}(x=0.1,0.4)$ films were measured, as shown in Fig. 3. For $x=0.1$, the Mn $2 p$ XPS peaks of the annealed and the post-heated films were not significantly different. However, for $x=0.4$, the peaks of $\mathrm{Mn} 2 p$ were heightened and attained a greater binding energy after the postheating process. This illustrates that the average state of the Mn in the post-heated films was higher than that of the annealed films. After experimental data normalization, we analyzed the $\mathrm{Mn} 2 p_{3 / 2}$ XPS spectra of the films by applying a peak synthesis procedure, as per Fig. $3 \mathrm{~b}-\mathrm{e}$, and summarized the relative concentration of $\mathrm{Mn}^{3+}(642.8 \mathrm{eV})$ and $\mathrm{Mn}^{4+}$ $(644.2 \mathrm{eV})$ cations in Table I. ${ }^{17}$ It can be seen that the $\mathrm{Mn}^{3+} / \mathrm{Mn}^{4+}$ ratios were $2.948,2.844,2.812$, and 2.049 for the $\mathrm{Mn}_{1.56}\left(\mathrm{Co}_{1-\mathrm{x}} \mathrm{Al}_{\mathrm{x}}\right)_{0.96} \mathrm{Ni}_{0.48} \mathrm{O}_{4}(x=0.1)$ film, the post-heated $\mathrm{Mn}_{1.56}\left(\mathrm{Co}_{1-\mathrm{x}} \mathrm{Al}_{\mathrm{x}}\right)_{0.96} \mathrm{Ni}_{0.48} \mathrm{O}_{4}$ $(x=0.1) \quad$ film, the $\mathrm{Mn}_{1.56}\left(\mathrm{Co}_{1-\mathrm{x}} \mathrm{Al}_{\mathrm{x}}\right)_{0.96} \mathrm{Ni}_{0.48} \mathrm{O}_{4}$ $(x=0.4)$ film, and the post-heated $\mathrm{Mn}_{1.56}$ $\left(\mathrm{Co}_{1-\mathrm{x}} \mathrm{Al}_{\mathrm{x}}\right)_{0.96} \mathrm{Ni}_{0.48} \mathrm{O}_{4}(x=0.4)$ film, respectively. Even after adding $\mathrm{Al}^{3+}$ cations, there was little 
Improvement of $\mathrm{Mn}_{1.56}\left(\mathrm{Co}_{1-\mathrm{x}} \mathrm{Al}_{\mathrm{x}}\right)_{0.96} \mathrm{Ni}_{0.48} \mathrm{O}_{4}(0.1 \leq x \leq 0.4)$ Film Preparation and Assessment
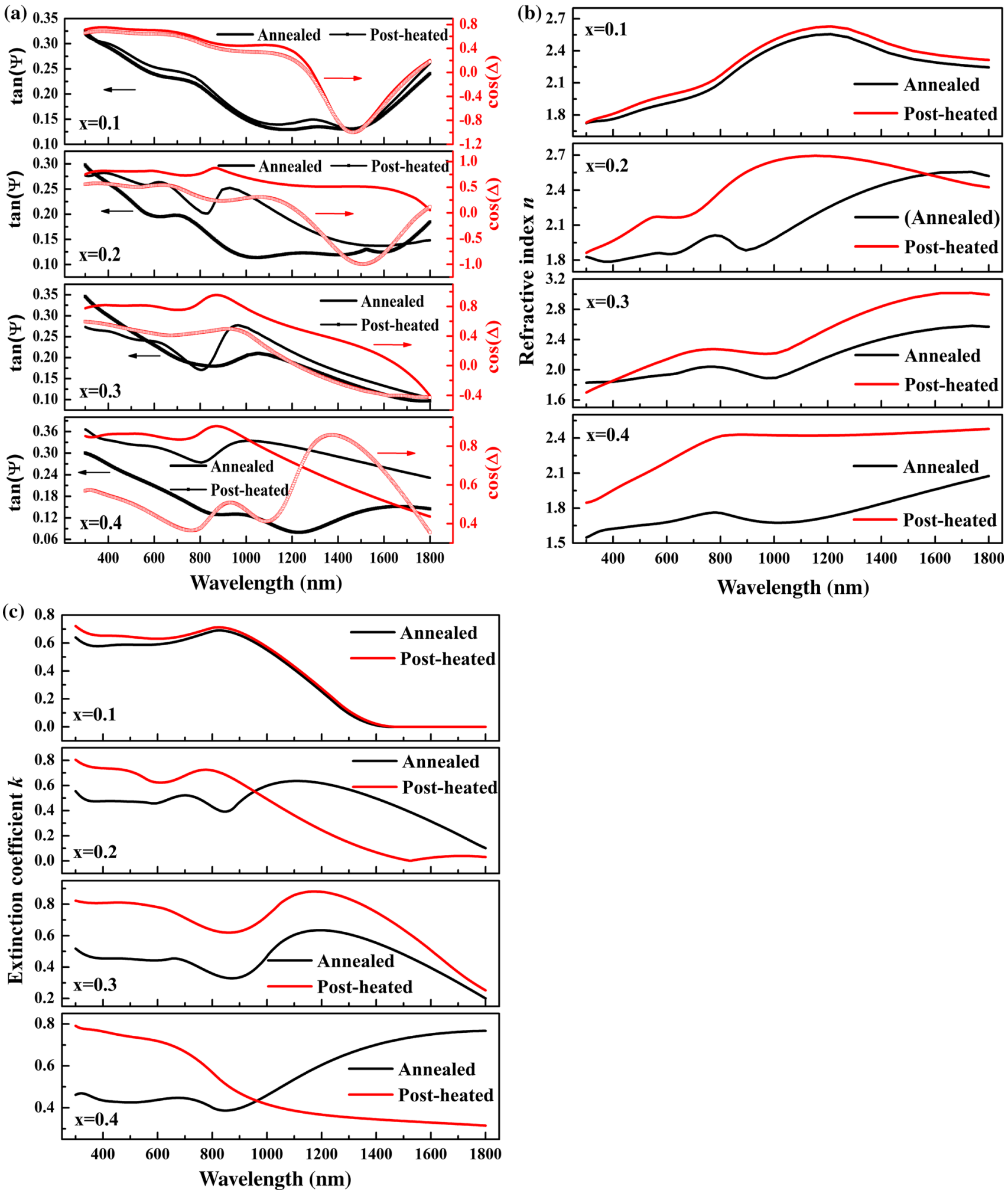

Fig. 5. (a) The fitting values of $\tan (\Psi)$ and $\cos (\Delta)$, (b) the refractive index $n$, and (c) the extinction coefficient $k$ of $\mathrm{Mn}_{1.56}\left(\mathrm{Co}_{1-x} \mathrm{Al}_{\mathrm{x}}\right)_{0.96} \mathrm{Ni}_{0.48} \mathrm{O}_{4}$ $(x=0.1,0.2,0.3$ and 0.4$)$ films.

change in the $\mathrm{Mn}^{3+} / \mathrm{Mn}^{4+}$ ratio. The $\mathrm{Mn}^{3+} / \mathrm{Mn}^{4+}$ ratios of the post-heated $\mathrm{Mn}_{1.56}\left(\mathrm{Co}_{1-\mathrm{x}} \mathrm{Al}_{\mathrm{x}}\right)_{0.96}$ $\mathrm{Ni}_{0.48} \mathrm{O}_{4}(x=0.1,0.2,0.3$ and 0.4$)$ films were lower than those of the $\mathrm{Mn}_{1.56}\left(\mathrm{Co}_{1-\mathrm{x}} \mathrm{Al}_{\mathrm{x}}\right)_{0.96} \mathrm{Ni}_{0.48} \mathrm{O}_{4}$ $(x=0.1,0.2,0.3$ and 0.4$)$ films, which will lead to different physical properties. 

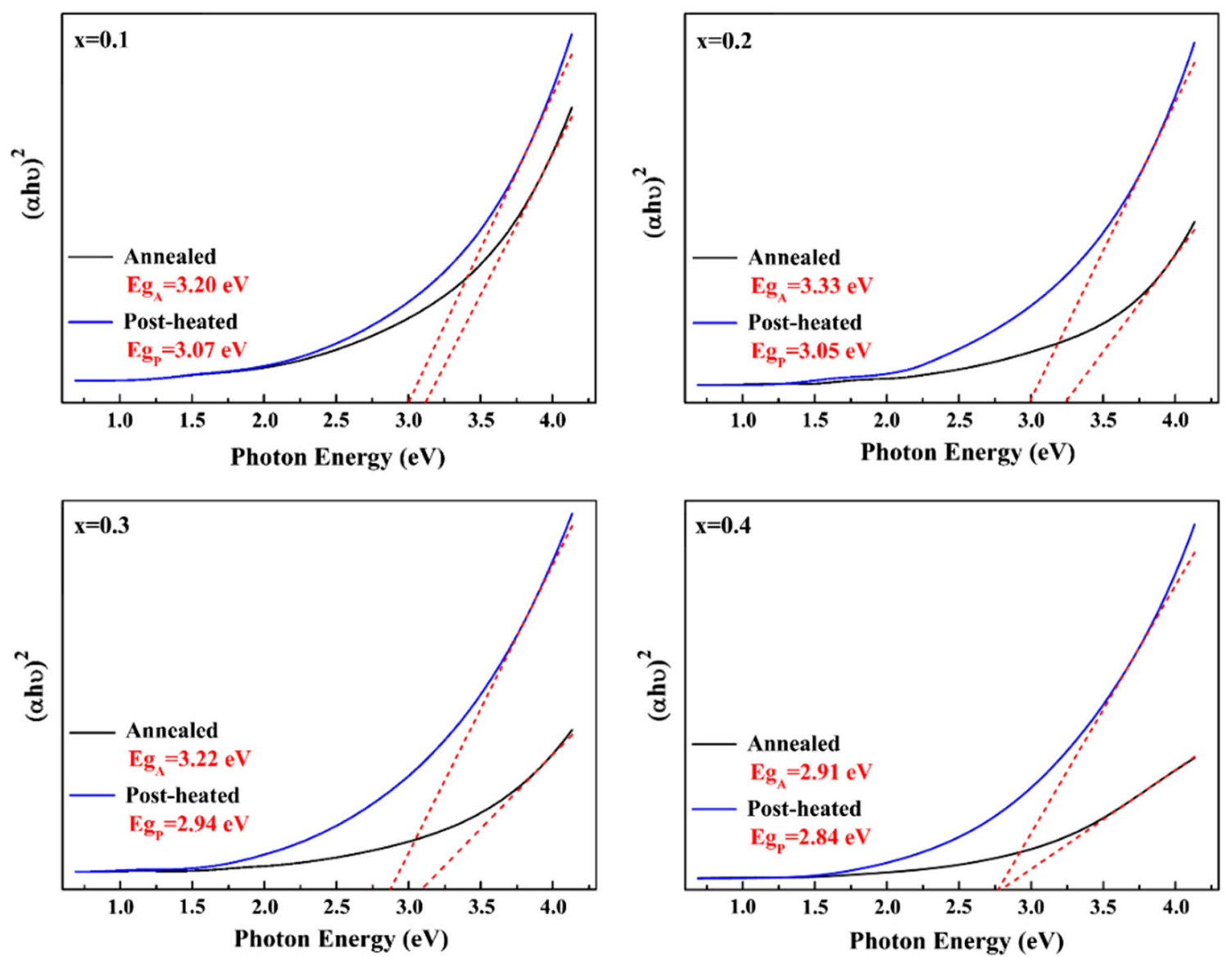

Fig. 6. The plots of $(\alpha h v)$ versus $(h v)$ for $\mathrm{Mn}_{1.56}\left(\mathrm{Co}_{1-x} \mathrm{Al}_{\mathrm{x}}\right)_{0.96} \mathrm{Ni}_{0.48} \mathrm{O}_{4}(x=0.1,0.2,0.3$ and 0.4$)$ films, and $E_{g}$ values are estimated by tangents.

Raman spectroscopy can provide useful information on the crystal orientation of thin crystal films. A series of $\mathrm{Mn}_{1.56}\left(\mathrm{Co}_{1-\mathrm{x}} \mathrm{Al}_{\mathrm{x}}\right)_{0.96} \mathrm{Ni}_{0.48} \mathrm{O}_{4}(x=0.1,0.2$, 0.3 and 0.4 ) film Raman spectra were measured at room temperature in the range $200-900 \mathrm{~cm}^{-1}$ (Fig. 4). The main vibration mode $\left(A_{1 g}\right)$ was located at around $620 \mathrm{~cm}^{-1}$, which is associated with the symmetric $\left[\mathrm{Mn}^{3+}-\mathrm{O}\right]$ stretching vibration in the octahedral unit of $\left[\mathrm{Mn}^{3+}-\mathrm{O}\right]_{6} \cdot{ }^{18,19}$ The Raman peaks located at around $500 \mathrm{~cm}^{-1}$ are assigned to the $\mathrm{F}_{2 \mathrm{~g}}$ mode, which originates from the symmetric bending vibration of $\left[\mathrm{Mn}^{4+}-\mathrm{O}\right]$ bonds. ${ }^{20}$ The positions, and the intensities of the $A_{1 g}$ and $F_{2 g}$ modes for $x \leq 0.2$ showed little difference between the annealed and post-heated films. However, the intensities of both the $A_{1 g}$ and $F_{2 g}$ modes of the $x \geq 0.3$ post-heated films decreased and shifted to the right due to the mean grain size of the $\mathrm{Mn}_{1.56}\left(\mathrm{Co}_{1-\mathrm{x}} \mathrm{Al}_{\mathrm{x}}\right)_{0.96} \mathrm{Ni}_{0.48} \mathrm{O}_{4}$ films $(x \geq 0.3)$ decreasing after the post-heating process.

A three-layer model (air/ $\mathrm{Mn}_{1.56}\left(\mathrm{Co}_{1-\mathrm{x}} \mathrm{Al}_{\mathrm{x}}\right)_{0.96} \mathrm{Ni}_{0.48} \mathrm{O}_{4}(x=0.1,0.2,0.3$ and 0.4) films/substrate) was built, and the Tauc-
Lorentz oscillator dispersion relationship was used for fitting and calculating the optical parameters. Two important ellipsometry parameters ( $\Psi$ and $\Delta$ ) were measured at room temperature, and are related to the physical amplitude and phase, respectively. The fitted values of $\tan (\Psi)$ and $\cos (\Delta)$ in the wavelength range of $300-1800 \mathrm{~nm}$ are shown in Fig. 5a. The model fitting was implemented by minimizing the mean square error (MSE) function defined as ${ }^{21}$ :

$\operatorname{MSE}=\frac{1}{2 N-M} \sum_{i=1}^{N}\left[\left(\frac{\psi_{i}^{\bmod }-\psi_{i}^{\exp }}{\sigma_{\psi i}^{\exp }}\right)^{2}\left(\frac{\Delta_{i}^{\bmod }-\Delta_{i}^{\exp }}{\sigma_{\Delta_{i}}^{\exp }}\right)^{2}\right]$

where $N$ is the number of $(\Psi, \Delta)$ pairs, $M$ is the number of variable parameters in the model, $\sigma$ is the standard deviation of the experimental points, and the superscripts mod and exp denote the calculated and experimental values, respectively. The mean square error values for the $\mathrm{Mn}_{1.56}\left(\mathrm{Co}_{1-\mathrm{x}} \mathrm{Al}_{\mathrm{x}}\right)_{0.96} \mathrm{Ni}_{0.48} \mathrm{O}_{4}(x=0.1,0.2,0.3$ and 
0.4 ) films (and aged films) were 0.3356 (0.2642), $0.2898(0.2257), 0.2722(0.3285)$, and $0.7816(0.8230)$ for $x=0.1,0.2,0.3$, and 0.4 , respectively. The optical constant refractive index $n$ and extinction coefficient $k$ were calculated as follows ${ }^{22}$ :

$$
\begin{aligned}
& n=\frac{1}{\sqrt{2}} \sqrt{\sqrt{\varepsilon_{1}^{2}+\varepsilon_{2}^{2}}+\varepsilon_{1}} \\
& k=\frac{1}{\sqrt{2}} \sqrt{\sqrt{\varepsilon_{1}^{2}+\varepsilon_{2}^{2}}-\varepsilon_{1}}
\end{aligned}
$$

where $\varepsilon_{1}$ and $\varepsilon_{2}$ are the real and imaginary components of the complex dielectric, respectively.

The refractive index $n$ of films in the range of 300-1800 nm are presented in Fig. 5b. The curves of the four films display trends that increase with wavelength. The refractive index $n$ of each $\mathrm{Mn}_{1.56}\left(\mathrm{Co}_{1-\mathrm{x}} \mathrm{Al}_{\mathrm{x}}\right)_{0.96} \mathrm{Ni}_{0.48} \mathrm{O}_{4}(x=0.1,0.2,0.3$ and 0.4) film had a peak after $900 \mathrm{~nm}$, except for the $x=0.4$ films. This is because the $x=0.4$ films have more numerous small particles than the others. ${ }^{16}$ Moreover, the curves $n$ of the post-heated films were higher than the annealed films in the visible wavelength range $(380-780 \mathrm{~nm})$.

According to Fig. 5c, the extinction coefficient $k$ curves have two peaks in the range of 300-1800 $\mathrm{nm}$. The difference between the $n$ and $k$ curves increases as the $\mathrm{Al}^{3+}$ content increases. The peaks of the postheated films were higher than the annealed films at wavelengths below $950 \mathrm{~nm}$, indicating that the post-heating treatment can enhance the films' absorption in the visible range. The $k$ curves of the $x=0.2$ and 0.4 post-heated films decreased compared with the annealed films after $950 \mathrm{~nm}$. For the post-heated films, the peaks of the $k$ curves shifted slightly to smaller wavelengths.

The band gap, $E_{g}$, of all the $\mathrm{Mn}_{1.56}\left(\mathrm{Co}_{1-\mathrm{x}} \mathrm{Al}_{\mathrm{x}}\right)_{0.96} \mathrm{Ni}_{0.48} \mathrm{O}_{4}(x=0.1,0.2,0.3$ and 0.4) films can be calculated by the Tauc equation: $(\alpha h v)^{2} \propto A\left(h v-E_{g}\right)$, in which the absorption coefficient, $\alpha$ can be determined by the Kramers-Kronig transformation: $\alpha=\frac{4 \pi k}{2}$ and $A$ is a constant. ${ }^{23-27}$ Figure 6 shows a plot of $\alpha h v$ versus $h v$ for the annealed and the post-heated films, illustrating that the absorption coefficients of all the films increase as a function of the photon energy. By extrapolating the straight-line portion of the plots of $(\alpha h v)^{2}$ versus $h v$ to the photon energy axis, we obtain $E_{g A}$ values for the annealed $\mathrm{Mn}_{1.56}\left(\mathrm{Co}_{1-\mathrm{x}} \mathrm{Al}_{\mathrm{x}}\right)_{0.96} \mathrm{Ni}_{0.48} \mathrm{O}_{4} \quad(x=0.1,0.2,0.3$ and 0.4 ) films of $3.20,3.33,3.22$, and $2.91 \mathrm{eV}$ for added$\mathrm{Al}^{3+}$ contents of $0.1,0.2,0.3$, and 0.4 , respectively. The corresponding $E_{\sigma P}$ values of the post-heated $\mathrm{Mn}_{1.56}\left(\mathrm{Co}_{1-\mathrm{x}} \mathrm{Al}_{\mathrm{x}}\right)_{0.96} \mathrm{Ni}_{0.48} \mathrm{O}_{4}(x=0.1,0.2,0.3$ and 0.4 ) films were $3.07,3.05,2.94$, and $2.84 \mathrm{eV}$. This demonstrates that the band gaps of all four $\mathrm{Mn}_{1.56}\left(\mathrm{Co}_{1-\mathrm{x}} \mathrm{Al}_{\mathrm{x}}\right)_{0.96} \mathrm{Ni}_{0.48} \mathrm{O}_{4}(x=0.1,0.2,0.3$ and 0.4 ) films decreased after the post-heating process.

\section{CONCLUSIONS}

$\mathrm{Mn}_{1.56}\left(\mathrm{Co}_{1-\mathrm{x}} \mathrm{Al}_{\mathrm{x}}\right)_{0.96} \mathrm{Ni}_{0.48} \mathrm{O}_{4}(x=0.1,0.2,0.3$ and 0.4 ) films were fabricated by the CSD method and then post-heated. The structural and optical properties of the annealed and the post-heated films were investigated, which showed that crystallinity and relative density improved after post-heating. The refractive index $n$ and the extinction coefficient $k$ values of the post-heated films were greater than those of the annealed films in the visible range, especially for $\mathrm{Mn}_{1.56}\left(\mathrm{Co}_{1-\mathrm{x}} \mathrm{Al}_{\mathrm{x}}\right)_{0.96} \mathrm{Ni}_{0.48} \mathrm{O}_{4}$ films with $x=0.3$ and 0.4 . Furthermore, the $\mathrm{Mn}^{3+} / \mathrm{Mn}^{4+}$ ratio decreased in the post-heated films, leading to significant decreases in the Raman mode intensity and band gap.

\section{ACKNOWLEDGMENTS}

This work was supported by the National Key Research and Development Program of China (Grant No. 2017YFB0406405), the National Natural Science Foundation of China (Grant No. 61804178) and the Xinjiang Uygur Autonomous Region of China (No. 2017D01B51).

\section{REFERENCES}

1. A. Feteira, J. Am. Ceram. Soc. 92, 967 (2009).

2. W. Zhou, J. Wu, C. Ouyang, Q.Y. Gao, X.F. Xu, and Z.M. Huang, J. Appl. Phys. 115, 056601 (2014).

3. B. Lavina, G. Salviulo, and A. Della Giusta, Phys. Chem. Miner. 29, 10 (2002).

4. F. Zhang, W. Zhou, C. Ouyang, J. Wu, Q.Y. Gao, and Z.M. Huang, AIP Adv. 5, 683 (2015).

5. M. Vakiv, O. Shpotyuk, O. Mrooz, and I. Hadzaman, J. Eur. Ceram. Soc. 21, 1783 (2001).

6. C. Rath, S. Anand, R.P. Das, K.K. Sahu, S. Kulkarni, S. Date, and N.C. Mishra, J. Appl. Phys. 91, 2211 (2002).

7. S. Jagtap, S. Gosavi, S. Rane, and D. Amalnerlar, Microelectron. Int. 26, 19 (2009).

8. K. Park and I.H. Han, Mater. Sci. Eng. B 119, 55 (2005).

9. Q. Shi, S. Bao, W. Ren, X.B. Zhang, J. Hu, N. Li, Q. Zhou, L. Wang, A.M. Chang, and L. Bian, Ceram. Int. 43, 5702 (2017).

10. P. Castelan, B. Ai, A. Loubiere, A. Rousset, and R. Legros, J. Appl. Phys. 72, 4705 (1992).

11. W.W. Kong, B. Gao, C.P. Jiang, and A.M. Chang, Appl. Mechan. Mater. 748, 11 (2015).

12. L. He and Z.Y. Ling, Appl. Phys. Lett. 98, 242112 (2011).

13. Y. Zhao, Y.A. Opata, W. Wu, and J.C. Grivel, Mater. Charact. 124, 58 (2017).

14. K. Parvez, S. Yang, X. Feng, and K. Müllen, Synth. Met. 210, 123 (2015)

15. R. Schmidt, A. Basu, A.W. Brinkman, Z. Klusek, and P.K. Datta, Appl. Phys. Lett. 86, 325 (2005).

16. C. Ma, W. Ren, L. Wang, L. Bian, J.B. Xu, and A.M. Chang, Mater. Lett. 153, 162 (2015).

17. J. Töpfer, A. Feltz, D. Gräf, B. Hackl, L. Raupach, and P. Weissbrodt, Phys. Status Solidi A 134, 405 (2010).

18. R. Lewandowska, M. Gaillet, G.L. Bourdon, C. Eypert, S. Morel, C. Naudin, and M. Stchakovsky, Surf. Interface Anal. 40, 588 (2008).

19. C. Ma, H.G. Wang, P.J. Zhao, J.B. Xu, A.M. Chang, L. Wang, and L. Bian, Mater. Lett. 136, 225 (2014).

20. P. Chandramohan, M.P. Srinivasan, S. Velmurugan, and S.V. Narasimhan, J. Solid State Chem. 184, 89 (2011). 
21. Y.Q. Gao, Z.M. Huang, Y. Hou, J. Wu, Y.J. Ge, and J.H. Chu, Appl. Phys. Lett. 94, 1114 (2009).

22. H.G. Wang, J.B. Xu, C. Ma, F.L. Xu, L. Wang, L. Bian, and A.M. Chang, J. Alloys Compd. 615, 526 (2014).

23. Y. Hou, J.Q. Xue, Z.M. Huang, T.X. Li, Y.J. Ge, and J.H. Chu, Thin Solid Films 517, 901 (2008).

24. P. Liu, P. Longo, A. Zaslavsky, and D. Pacifici, J. Appl. Phys. 119, 014304 (2016).

25. Y. Feng, S. Lin, S. Huang, S. Shrestha, and G. Conibeer, J. Appl. Phys. 117, 125701 (2015).
26. X.M. Li, H.W. Zhu, J.Q. Wei, K.L. Wang, E.Y. Xu, Z. Li, and D.H. Wu, Appl. Phys. A Mater. 97, 341 (2009).

27. B.D. Viezbicke, S. Patel, B.E. Davis, and D.P. Birnie, Phys. Status Solidi B 252, 1700 (2015).

Publisher's Note Springer Nature remains neutral with regard to jurisdictional claims in published maps and institutional affiliations. 